\title{
Tools for monitoring aquatic environments to identify anthropic effects
}

\author{
Monyque Palagano da Rocha • Priscila Leocadia Rosa Dourado • \\ Claudia Andrea Lima Cardoso • Liliam Silva Cândido • Joelson Gonçalves Pereira • \\ Kelly Mari Pires de Oliveira • Alexeia Barufatti Grisolia
}

Received: 2 May 2017 / Accepted: 26 December 2017 / Published online: 5 January 2018

(C) Springer International Publishing AG, part of Springer Nature 2018

\begin{abstract}
Anthropic activities are directly related to the contamination of aquatic ecosystems owing to the release of numerous chemicals from agricultural and urban waste. These contaminants cause environmental degradation and a decrease in the availability of water quality. The objective of this search was to evaluate the efficiency of physicochemical, chemical, and microbiological tests; extraction of chlorophyll $a$; and genetic parameters to identify anthropic activities and weather condition effects on the stream water quality and the consequences of its use by the population. The
\end{abstract}

\section{P. da Rocha $(\square)$}

FACET, Faculty of Exact Sciences and Technology/UFGD, Federal University of Grande Dourados, University City of Dourados, Rodovia Dourados/Itahum, Dourados, Mato Grosso do Sul, Brazil

e-mail: monyque_da_rocha@hotmail.com

\section{P. L. R. Dourado}

IBILCE, Institute of Biosciences, Arts and Exact Sciences/ UNESP, Paulista State University Júlio de Mesquita Filho, São José do Rio Preto Campus, Rua Cristóvão Colombo, 2265, Jardim Nazareth, São José do Rio Preto, São Paulo, Brazil

C. A. L. Cardoso

CERNA, Center for Studies in Natural Resources/UEMS, State University of Mato Grosso do Sul, University City of Dourados, Rodovia Dourados/Itahum, Dourados, Mato Grosso do Sul, Brazil

L. S. Cândido · J. G. Pereira · K. M. P. de Oliveira •

A. B. Grisolia

FCBA, Faculty of Biological and Environmental Sciences/UFGD, Federal University of Grande Dourados, University City of Dourados, Rodovia Dourados/Itahum, Dourados, Mato Grosso do Sul, Brazil physicochemical parameters were within the limits allowed by the Brazilian law. However, contamination by metals (Cd $0.510 \mathrm{mg} \mathrm{L}^{-1}$, Co $0.405 \mathrm{mg} \mathrm{L}^{-1}$, and Ni $0.316 \mathrm{mg} \mathrm{L}^{-1}$ ) has been found at various collection points to be more than the allowable values. The antibiotic oxytetracycline was detected in stream water in quantities of up to $89 \mu \mathrm{g} \mathrm{L}^{-1}$. In relation to microbiological contamination, Escherichia coli and Pseudomonas spp. have been isolated. The averages of chlorophyll $a$ were up to $0.15558 \mathrm{mg} \mathrm{cm}^{-2}$. Genetic tools identified greater number of micronuclei and DNA damage in periods that showed lower rainfall rates and lower amounts of metals. The analysis used for monitoring was efficient to verify the interference that animal breeding and planting of different cultures have caused on that stream. Thus, the continued use of this water for drinking, irrigation of vegetables, and recreational activities makes the population susceptible to contamination by bacteria and creates conditions for the development of genetic alterations in the long run.

Keywords Surface water $\cdot$ Microbiology $\cdot$ Genetic parameter $\cdot$ Environmental pollutants

\section{Introduction}

The lack of basic sanitation, improper disposal of solid waste, excessive use of agro-chemicals, leaching in soil without a vegetation cover, and untreated effluent discharges, in large volumes, are the main problems 
regarding the contamination of watercourses (Callisto and Gonçalves Jr 2002; Tiefenthaler et al. 2011).

Activities related to agriculture and animal breeding also contribute to increase the amount of chemicals released into the environment, in particular, into aquatic environments. The need for increased productivity, in search for better agricultural yields, promotes the indiscriminate use of chemical compounds, with consequences to the environment and public health (Ventura et al. 2008). In this context, Brazil is the world's fourth largest consumer of chemical substances used in agricultural activities, and the biggest expense is made with pesticides, mainly for soybean crops (approximately 35\%) (Santos and Monteiro 2004).

The release of chemical compounds in water results in higher concentrations than those found naturally, and as a result, there are changes in the microenvironment and the natural physicochemical composition of the rivers, the vegetation that covers the banks, the color of the water, and the existing biota (Callisto et al. 2005). The use of different parameters in a biomonitoring study allows the evaluation of the impact on the environment of contaminated urban, industrial, and agricultural wastes (Rocha et al. 2015).

The evaluation of physicochemical and biological parameters in water bodies is an evidence of the anthropic, agrarian, and industrial interferences (Goulart and Callisto 2003). The physical and chemical parameters measured are temperature, $\mathrm{pH}$, and oxygen saturation (Okeke et al. 2011; Gemmell and Schmidt 2013). For chemicals, tests are made on metals and organic compounds (Schipper et al. 2008). Moreover, for microbiological parameters, analyses of coliforms, Escherichia coli, Salmonella spp., and Pseudomonas spp. (Rowny and Stewart 2012; Kittinger et al. 2013) and extraction of chlorophyll $a$ (Siqueira and Rodrigues 2009) are performed. Furthermore, for biological parameters, animal bioassays are carried out using the micronucleus piscine test with Astyanax lacustris (Silva et al. 2011) and the Comet Assay with A. lacustris (Gontijo and Tice 2003).

The "Curral de Arame" stream receives constant anthropic interference that does not exceed a length of $30 \mathrm{~km}$ and is located on the watershed of the sub-basins of Brilhante and Dourados Rivers, both belonging to the Ivinhema River Basin (de Lima 1999) and in a region of the Cwa climate type (humid mesothermal climate, warm summers, and dry winters), where the temperature of the coldest months (June and July) is below $18^{\circ} \mathrm{C}$ and that of the hottest month (January) is above $22{ }^{\circ} \mathrm{C}$. In addition, the total rainfall in summer exceeds by more than ten times the lowest monthly rainfall (July) (Fietz and Fisch 2008). The study assessed the efficiency of analysis for monitoring of aquatic environments (physicochemical, chemical, and microbiological tests; extraction of chlorophyll $a$; and genetic parameters) to identify anthropic activities and weather condition interferences on the stream water quality.

\section{Materials and methods}

Study area

The urban perimeter of Dourados is at an average altitude of $430 \mathrm{~m}$ above sea level (m a.s.l.), latitude of $22^{\circ} 13^{\prime} 16^{\prime \prime} \mathrm{S}$, and longitude of $54^{\circ} 48^{\prime} 20^{\prime \prime} \mathrm{W}$, with a total area of $4,086,237 \mathrm{~km}^{2}$ and 212,870 inhabitants (IBGE-Instituto Brasileiro de Geografia e Estatística 2013). Among the streams located in the region of Grande Dourados (that covers 10 municipalities in its vicinity), "Curral de Arame" stream, located in the basin of the Dourados River (MS, Brazil) is influenced by local agriculture. The water source is located in a native bushland reserve, passing through places of intense agricultural activity (sugar cane, corn, and soy), and flowing into the Dourados River, where water collection is performed for public consumption of the entire city.

\section{Collection points}

The monitoring of the "Curral de Arame" stream was conducted in the months of January, March, May, August, September, and November 2013, with a total of six collections in each sampling spot, namely Points 1, 2, and 3 (Fig. 1).

Point $1(\mathrm{P} 1)\left(22^{\circ} 12^{\prime} 48.83^{\prime \prime} \mathrm{S}\right.$ and $\left.054^{\circ} 54^{\prime} 41.06^{\prime \prime} \mathrm{W}\right)$ is located in the source of the stream within the protected area, although inhabited. In addition, Point 2 (P2) $\left(22^{\circ} 15^{\prime} 36.69^{\prime \prime} \mathrm{S}\right.$ and $\left.054^{\circ} 52^{\prime} 40.81^{\prime \prime} \mathrm{W}\right)$ is located $0.5 \mathrm{~km}$ of sugarcane plantation areas and receives agrochemical effluents from these. Furthermore, Point 3 (P3) $\left(22^{\circ} 20^{\prime} 16.07^{\prime \prime} \mathrm{S}\right.$ and $\left.054^{\circ} 50^{\prime} 48.23^{\prime \prime} \mathrm{W}\right)$ is located $7.4 \mathrm{~km}$ away from the mouth of the Dourados River receiving interference from agrochemicals used in sugarcane plantation (Point 2) and corn and soybean crops planted near the banks. 


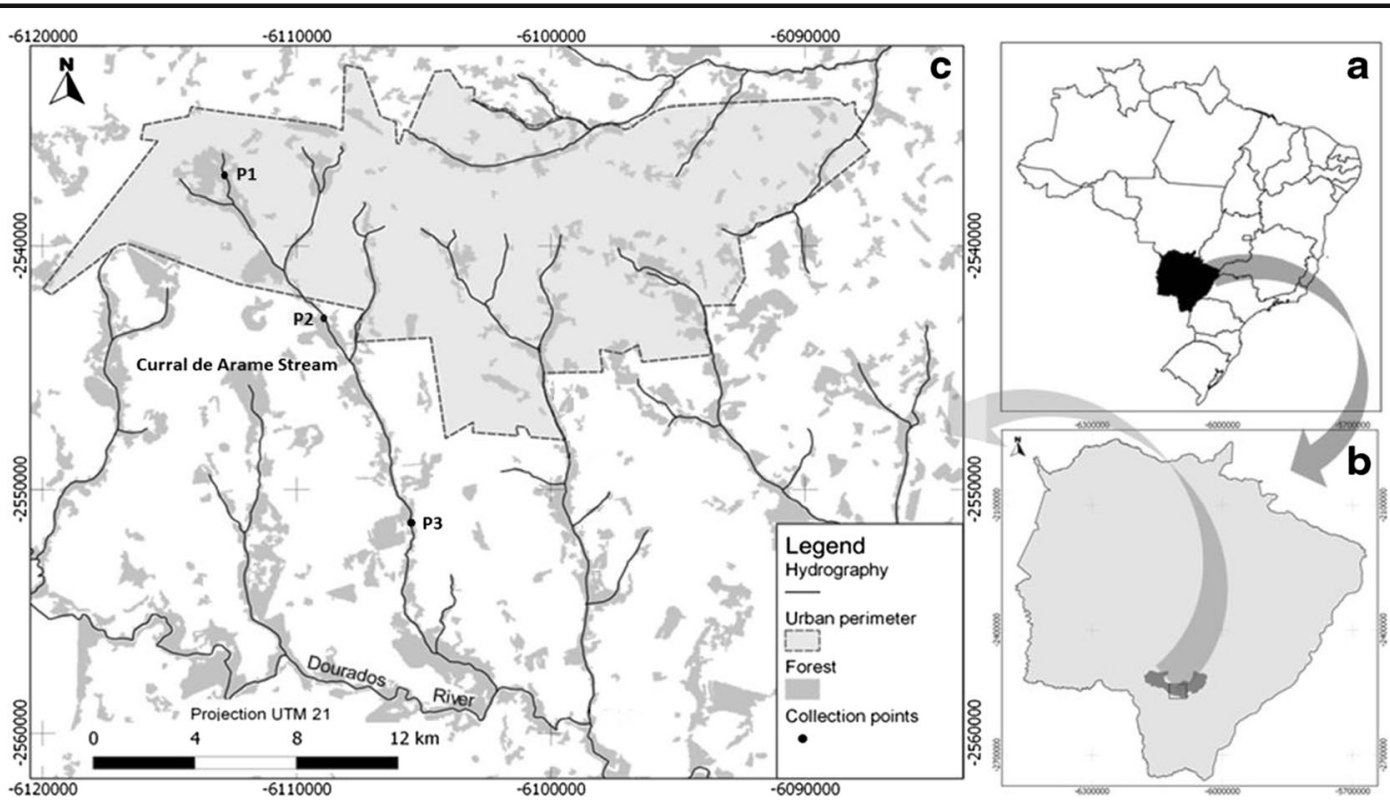

Fig. 1 Map of the State of Mato Grosso do Sul (a), Dourados municipality (b), and collection points (P1, P2, and P3) at the Curral de Arame Stream (c)

Water collection procedures

Water samples for metal and organic compound analysis were collected in amber bottles of $1 \mathrm{~L}$. The samples were frozen $\left(-20{ }^{\circ} \mathrm{C}\right)$ for the determination of organic compounds, and for metals, the water were acidified with nitric acid $(1 \mathrm{~mL})$ and refrigerated $\left(2\right.$ to $\left.8{ }^{\circ} \mathrm{C}\right)$.

Water samples were collected in sterile glass bottles of $500 \mathrm{~mL}$ by submerging to a $20 \mathrm{~cm}$ depth on the stream bank for microbiological testing. The samples were transported in a refrigerated cooler with an 8 -h time interval between the collection of the water samples and the microbiological test.

For the evaluation of other parameters, water samples were collected in previously cleaned $20 \mathrm{~L}$ flasks.

Physico-chemical analyses

A Hanna HI 9829 multi-parameter probe was used to measure in situ the following: water temperature $\left({ }^{\circ} \mathrm{C}\right)$, hydrogen potential $(\mathrm{pH})$, and dissolved oxygen $\left(\mathrm{mg} \mathrm{L}^{-1}\right)$. The rainfall index was calculated from data of means of 15 days of rain that preceded the collection. These data came from the Embrapa Centro Oeste (EMBRAPA 2014).
Metal detection

Instrumentation, sample preparation, and analysis

An Agilent AA 240FS flame atomic absorption spectrometer (Agilent Technologies ${ }^{\circledR}$, Santa Clara, CA, USA) equipped with a deuterium background corrector and mono element hollow cathode lamps was used throughout this study. High-purity acetylene $(99.7 \%$, White Martins ${ }^{\circledR}$, Brazil) and nitrous oxide $(99.9 \%$, White Martins ${ }^{\circledR}$, Brazil) were used for flame composition for atomization of metal analysis by air-acetylene flame. Considering that $\mathrm{Cu}, \mathrm{Fe}, \mathrm{Mn}, \mathrm{Cd}, \mathrm{Co}$, and $\mathrm{Ni}$ are used in agrochemicals in the region of Grande Dourados, these compounds were selected for this study. The parameters, such as wavelength, hollow cathode lamp current, slit setting, and gas flow rate, were adjusted under optimum conditions, and the results are shown in Table 1. All measurements were carried out in five replicates.

High-purity de-ionized water obtained using a Millipore Milli-Q Academic $®$ deionizer system (resistivity of $18.2 \mathrm{M} \Omega \mathrm{cm}$, Millipore, Bedford, MA, USA) and nitric acid $\left(65 \%(\mathrm{~m} / \mathrm{v})\right.$, Sigma-Aldrich ${ }^{\circledR}$, USA) were used to prepare the analytical solutions and samples. All solutions were stored in glassware bottles, cleaned by soaking in $10 \%(v / v) \mathrm{HNO}_{3}$ for at least 
Table 1 Physicochemical analysis of water samples from P1, P2, and P3 in the "Curral de Arame" stream

\begin{tabular}{lrrrr}
\hline Physicochemical parameters & P1 & P2 & P3 & CONAMA ${ }^{\mathrm{a}}$ parameters \\
\hline Water temperature $\left({ }^{\circ} \mathrm{C}\right)$ & 24.5 & 24.8 & 28.6 & Less than $40{ }^{\circ} \mathrm{C}$ \\
$\mathrm{pH}$ & 7.4 & 7.4 & 7.6 & 6.0 to 9.0 \\
Dissolved oxygen $\left(\mathrm{mg} \mathrm{L}^{-1}\right)$ & 7.4 & 5.6 & 8.7 & ${\text { Not less than } 4 \mathrm{mg} \mathrm{L}^{-1}}$ \\
\hline
\end{tabular}

${ }^{a}$ Brazilian Resolution CONAMA no. 357/2005

$24 \mathrm{~h}$, and thoroughly rinsed in de-ionized water before use.

For sample pretreatment procedure, $200 \mathrm{~mL}$ water was transferred to an Erlenmeyer flask followed by $10.0 \mathrm{~mL} \mathrm{HNO}_{3}$. The mixture was submitted to a heating block system at $90{ }^{\circ} \mathrm{C}$ to reduce and concentrate the water samples to $30 \mathrm{~mL}$. The final volume was adjusted up to $50 \mathrm{~mL}$ with $1.0 \%(v / v) \mathrm{HNO}_{3}$ solution. All samples were prepared in triplicate.

For the main atomic lines for $\mathrm{Cu}, \mathrm{Fe}, \mathrm{Mn}, \mathrm{Cd}, \mathrm{Co}$, and $\mathrm{Ni}, 5.0 \mathrm{~mL} \mathrm{~min}^{-1}$ sample flow rate and multielement calibration curves within the $0.1-2.0 \mathrm{mg} \mathrm{L}^{-1}$ $\mathrm{Cu}, 0.5-4.0 \mathrm{mg} \mathrm{L}^{-1} \mathrm{Fe}, 0.2-4.0 \mathrm{mg} \mathrm{L}^{-1} \mathrm{Mn}, 0.2-$ $10.0 \mathrm{mg} \mathrm{L}^{-1} \mathrm{Cd}, 0.2-10.0 \mathrm{mg} \mathrm{L}^{-1} \mathrm{Co}$, and $0.2-$ $10.0 \mathrm{mg} \mathrm{L}^{-1} \mathrm{Ni}$ ranges were consistently obtained. All measurements were carried out in five replicates. The limit of detection (LOD) and limit of quantification (LOQ) were calculated according to the IUPAC.

\section{Determination of organic compounds}

\section{Extraction of water constituents}

The water samples $(200 \mathrm{~mL})$ were subjected to the solid phase extraction (SPE). The cartridge was conditioned with ultrapure water and subsequently, $200 \mathrm{~mL}$ of the sample was eluted by SPE. The constituents that adhered to the cartridge were eluted with $20 \mathrm{~mL}$ methanol followed by $20 \mathrm{~mL}$ ethyl acetate. The methanol and ethyl acetate fractions of each sample were combined and evaporated. Subsequently, the fractions were diluted in $100 \mu \mathrm{L}$ methanol, filtered through a $0.20-\mu \mathrm{m}$ membrane, and analyzed by high-performance liquid chromatography (HPLC).

\section{HPLC analysis}

The samples and standards were analyzed in an analytical HPLC (Varian 210) system with a ternary solvent delivery system equipped with an auto-sampler, a photodiode array detector (PAD). The column was a C-18 $(25 \mathrm{~cm} \times 4.6 \mathrm{~mm}$; particle size, $5 \mu \mathrm{m}$; Luna, Phenomenex, Torrance, CA, USA). In each analysis, the flow rate and the injected volume were set as

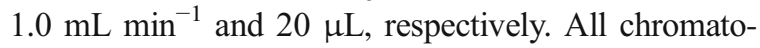
graphic analyses were performed at $25^{\circ} \mathrm{C}$. Considering that carbendazim is a fungicide widely used in soybean crops and thiamethoxam is an insecticide used in corn and sugarcane crops, these agrochemicals were used for analyses. Elution for carbendazim (CAS no. 10605-217) and thiamethoxam (CAS no. 15-3719-23-4) was carried out using acetonitrile (A) and water (B) 65:35 for $5.50 \mathrm{~min}$. The solvent gradient program was set at $0 \mathrm{~min}, 35 \%$ B for $5.50 \mathrm{~min}, 40 \% \mathrm{~B}$ for $15 \mathrm{~min}$, and $20 \%$ $\mathrm{B}$ for $18 \mathrm{~min}$ and returned to the initial analysis time at $20 \mathrm{~min}$. Oxytetracycline is an antibiotic widely used in treatment of respiratory diseases in breeding animals. The elution of oxytetracycline (CAS no. 79-57-2) was carried out using $28 \%$ acetonitrile and $72 \% 0.01 \mathrm{~mol} \mathrm{~L}^{-1}$ oxalic acid.

\section{Linearity and detection limits}

In the region of Grande Dourados, there is intense cultivation of soybeans, maize, and sugar cane where the compounds carbendazim and thiamethoxam are widely used for these plantations. In this area are also developed activities related to creation of animals, where antibiotics can be constantly used, among these we can highlight oxytetracycline. This way the content estimation of the standards oxytetracycline, cabendazim, and tiametoxam in the samples was performed by external calibration by HPLC, and each determination was carried out five times (1$100 \mu \mathrm{g} \mathrm{mL}^{-1}$ ). The detection limits were determined by injecting $(n=5)$ standard solutions of known concentration and then decreasing the concentrations of the samples until peak detection with a signal/noise ratio of 3 . 
Microbiological analysis

The techniques used to quantify water microorganisms were based on the Standard Methods for the Examination of Water and Wastewater, published by the American Public Health Association (APHA, AWWA, and WEF 2005).

\section{Research on total and thermo-tolerant coliforms and E. coli}

For the analysis of coliforms, the most probable number (MPN) technique was used, with serial dilution of the sample and using a triplicate of three tubes of lauryl tryptose broth (Merck, Darmstadt, Germany). Later, the brilliant green bile broth (BGBB) (HiMedia Laboratories Ltd., Mumbai, India) was used for confirmation of total coliforms and the EC Broth (Isofar, Rio de Janeiro, Brazil) for confirmation of thermo-tolerant coliforms. The number of total coliforms was determined by MPN. E. coli was isolated in EC broth on EMB (eosin methylene blue agar) agar plates (HiMedia Laboratories Ltd., Mumbai, India). The colonies with a metallic green sheen underwent biochemical identification (APHA, AWWA, and WEF 2005; Silva et al. 2010).

\section{Research on Salmonella spp.}

A buffered peptone water pre-enrichment (HiMedia Laboratories Ltd.) and the selective enrichment in selenite cystine broth (SC) (Isofar) and Rappaport Vassiliadis broth (RV) (Isofar) were used for the detection of Salmonella spp. In addition, for the isolation of the microorganism, xylose-lysine-desoxycholate agar (XLD) (Isofar) was used (APHA, AWWA, and WEF 2005; Silva et al. 2010). The colonies with a transparent halo and a central black spot were selected by the biochemical methods TSI (triple sugar iron agar), MIO (motility, indole, and ornithine), and urea.

\section{Research on Pseudomonas spp.}

For the analysis of Pseudomonas spp., $10 \mathrm{~mL}$ of the water sample was enriched in buffered peptone water (HiMedia Laboratories Ltd.) and, after 24 h, inoculated by using a discontinuous streak technique, in duplicate, using selective cetrimide agar (Merck) plates according to the methodology proposed by Oliveira et al. (2013). The plates with bacteriological growth were considered positive for Pseudomonas spp. (APHA, AWWA, and WEF 2005; Silva et al. 2010).

\section{Extraction of chlorophyll a}

Chlorophyll $a$ was extracted from algae belonging to the periphytic community. The experiment was carried out in three plastic slides of polyethylene terephthalate (PET) having a size of $2.5 \times 7.5 \mathrm{~cm}$, with approximately $18.75 \mathrm{~cm}^{2}$, and an artificial substrate for the development of the periphytic community in it. The slides have been set into the stream 15 days before each collection and submerged at a $30 \mathrm{~cm}$ water depth. After this period, the slides were removed from the stream and placed in $50 \mathrm{~mL}$ tubes filled with stream water. The slides were then stored in a cooler with ice until the analysis began. The procedures followed the method described by Siqueira and Rodrigues (2009).

Biological analysis

\section{Animal bioassays}

The water samples from points $\mathrm{P} 1, \mathrm{P} 2$, and $\mathrm{P} 3$ were placed in aerated glass tanks $(40 \times 30 \times 20 \mathrm{~cm})$ at room temperature $\left(23^{\circ} \mathrm{C}\right)$ for $24 \mathrm{~h}$. After this period, ten fishes (A. lacustris) from a commercial fish farm were placed in these tanks for $72 \mathrm{~h}$, five were used for micronucleus test, and another five for Comet Assay.

The procedures for conducting the animal experiments were approved by the ethics committee on animal research of the UFGD, protocol $n^{\circ} 005 / 2013$.

\section{Micronucleus piscine test on A. lacustris}

Specimens of A. lacustris were removed from the tanks after a 72-h treatment and anesthetized with benzocaine $2 \%$ (soluble). Then, a cut was made in the caudal fin to collect blood for blood extension.

The micronucleus count of erythrocytes followed the protocol described by Schmid (1975) and Heddle et al. (1983). The blood was collected in the caudal region, and a peripheral blood smear was made on the surface of the slide (two for each fish). The slides were fixed in ethanol and stained with Rapid Panoptic LB (Laborclin, Pinhais, Brazil). A total of 2000 cells was counted for each fish. Only red blood cells with intact cell and cytoplasmic membrane were considered. The counting of micronuclei was made on a Nikon optical microscope 
(400×), and the frequency of micronuclei was calculated (total number of cells with micronucleus / total number of cells observed $\times 100$ ).

\section{Comet Assay on A. lacustris}

The Comet Assay was adapted from the methodology of Ramsdorf et al. (2009). Six microliters of blood was collected by gill puncture and diluted in $2000 \mu \mathrm{L}$ of saline solution (PBS). Two slides from each fish were made of $20 \mu \mathrm{L}$ of cell suspension and $120 \mu \mathrm{L}$ of low melting point $0.5 \%$ agarose $(v / v)$ at $37{ }^{\circ} \mathrm{C}$. The slides remained in a lysis solution at $4{ }^{\circ} \mathrm{C}$ for $1 \mathrm{~h}$. After lysis, the slides were stored on a $0.3 \mathrm{~mol} \mathrm{~L}^{-1} \mathrm{NaOH}$ buffer and $0.001 \mathrm{~mol} \mathrm{~L}^{-1}$ EDTA $(\mathrm{pH}>13$ ) for $20 \mathrm{~min}$ and subjected to electrophoresis at $25 \mathrm{~V}, 300 \mathrm{~mA}$, for $20 \mathrm{~min}$. Then, the slides were neutralized with $0.4 \mathrm{~mol} \mathrm{~L}^{-1}$ Tris for $15 \mathrm{~min}$, fixed in ethanol, and stained with $0.02 \mathrm{~mol} \mathrm{~L}^{-1}$ ethidium bromide. A total of 100 nucleoids from each slide were observed with a fluorescence microscope (Labomed-T121100) with a $400 \times$ lens.

The nucleoids were classified according to the size of the "tail" as Class 0 (no damage), Class 1 (slightly damaged), Class 2 (intermediate damage), Class 3 (damaged), and Class 4 (high damage). Slide analysis was always performed by the same technician. For DNA damage evaluation, cell score (CS) was calculated using the following formula: (percentage of cells in Class $0 \times$ $0)+($ percentage of cells in Class $1 \times 1)+($ percentage of cells in Class $2 \times 2)+($ percentage of cells in Class $3 \times$ $3)+($ percentage of cells in Class $4 \times 4)$.

\section{Statistical analysis}

Data on extraction of chlorophyll $a$ and the frequency of micronuclei (MCN) and cell score (CS), from the animal bioassays, were subjected to analysis of variance and then to Duncan's test at a 0.05 probability to compare the averages using the BioEstat 4.0 program (Ayres et al. 2005).

\section{Results and discussion}

Physicochemical analysis

The values for physicochemical analysis were within the allowable values according to the National
Environmental Council (CONAMA) (357/2005) for P1, P2, and P3 (Table 1).

Metal detection

The concentrations of $\mathrm{Cd}, \mathrm{Co}$, and $\mathrm{Ni}$ were above the permissible limits at all collection points (P1, $\mathrm{P} 2$, and P3) according to the CONAMA (357/ 2005) (Table 2), which places the stream into a Class 3 water classification (intended to supply for human consumption after conventional or advanced treatment; irrigation of trees, cereals, and fodder crops, amateur fishing, secondary contact recreation, and livestock watering). In addition, these metals could affect aquatic biodiversity (Ribeiro et al. 2012).

Bermudez et al. (2009) reported that human activities, including industry, mining, and agriculture, can be cited as sources of pollution for the incorporation of metals in the environment. We can mention that the main sources of metal contamination in the "Curral de Arame" stream are related to agricultural activities by percolation of waste from insecticides, herbicides, fungicides, and fertilizers, considering that these metals are present in these products.

The copper found were lesser than the quantification limit of procedure $\left(0.026 \mathrm{mg} \mathrm{L}^{-1}\right)$ but higher than the CONAMA parameter $\left(0.013 \mathrm{mg} \mathrm{L}^{-1}\right)$. This fact suggested that the concentration of $\mathrm{Cu}$ could be higher than the parameter allowed, considering that this is a micronutrient used in chemical fertilization.

P3 showed a higher concentration of metals, and among the metals tested, both $\mathrm{Cd}\left(0.510 \mathrm{mg} \mathrm{L}^{-1}\right)$ and $\mathrm{Ni}\left(0.316 \mathrm{mg} \mathrm{L}^{-1}\right)$ were above the limits allowed by the Brazilian legislation (Ministerio do Meio Ambiente-CONAMA 2005). This may be related to the dragging power of water near the mouth of the stream and receiving interference from agrochemicals used in agriculture.

Bayen (2012) reported the difficulty to identify the source of metal pollution into the water, because it can be a combination of natural and anthropogenic sources, diffuse or occasional. High level of copper, cadmium, nickel, and other metals was found in the spots; the detection of lead, arsenic, cadmium, nickel, and manganese is related to agricultural activities, as these elements are present in agricultural supplies (Schipper et al. 2008; Rocha et al. 2015). 
Table 2 Metal concentrations (mean and standard deviation (SD), $\mathrm{mg} \mathrm{sL}^{-1}$ ) in water from the "Curral de Arame" stream

\begin{tabular}{lllllll}
\hline \multicolumn{7}{l}{ Elements $\left(\mathrm{mg} \mathrm{L}^{-1}\right)$} \\
\cline { 2 - 7 } & Copper (Cu) & Iron (Fe) & Manganese (Mn) & Cadmium (Cd) & Cobalt (Co) & Nickel (Ni) \\
\hline P1 & $<\mathrm{LQ}$ & $0.651 \pm 0.018$ & $0.026 \pm 0.002$ & $0.071 \pm 0.003$ & $0.280 \pm 0.024$ & $0.236 \pm 0.009$ \\
P2 & $<\mathrm{LQ}$ & $1.464 \pm 0.041$ & $0.092 \pm 0.004$ & $0.085 \pm 0.004$ & $0.405 \pm 0.008$ & $0.263 \pm 0.016$ \\
P3 & $<\mathrm{LQ}$ & $1.610 \pm 0.044$ & $0.115 \pm 0.010$ & $0.510 \pm 0.002$ & $0.303 \pm 0.021$ & $0.316 \pm 0.011$ \\
CONAMA* parameters & 0.013 & 5.0 & 0.5 & 0.01 & 0.2 & 0.025 \\
\hline
\end{tabular}

LQ limit of quantification (mg L ${ }^{-1}$ ): $\mathrm{Cu} 0.026, \mathrm{Fe} 0.049, \mathrm{Mn} \mathrm{0.017,} \mathrm{Cd} \mathrm{0.029,} \mathrm{Co} \mathrm{0.073,} \mathrm{and} \mathrm{Ni} \mathrm{0.062.} \mathrm{LOD} \mathrm{limit} \mathrm{of} \mathrm{detection} \mathrm{(mg} \mathrm{L}{ }^{-1}$ ): Cu 0.008, Fe 0.015, Mn 0.005, Cd 0.008, Co 0.021, and Ni 0.019. *Brazilian Resolution CONAMA no. 357/2005

Determination of organic compounds

The antibiotic oxytetracycline was found in greater concentration in P3 $\left(89 \mu \mathrm{g} \mathrm{L}^{-1}\right)$, followed by P2 $\left(53 \mu \mathrm{g} \mathrm{L}^{-1}\right)$ and P1 $\left(51 \mu \mathrm{g} \mathrm{L}^{-1}\right)$. The drug detection analysis in natural environments is used as a marker of human activities, since these drugs are found in aquatic environments due to the action of man (Kasprzyk-Hordern et al. 2009).

Research conducted in freshwater environments in Spain (Vazquez-Roig et al. 2011; Andreu et al. 2016) evaluated the presence of antibiotics (ciprofloxacin, norfloxacin, ofloxacin, oxytetracycline, sulfamethoxazole, tetracycline, and trimethoprim), but oxytetracycline has not been quantified. However, in the present study, this drug was detected in all collection spots. Such contamination may be related to the contamination of urban waste water, operations in animal feeding, industrial waste effluents, and uncontrolled landfills.

Microbiological analysis

\section{Total coliforms and E. coli}

The highest values found for total coliforms occurred in the August collection at P2 (240 NMP/100 mL), May at P3 (460 NMP/100 mL), and November at P3 (460 NMP/100 mL) (Fig. 2). According to the CONAMA's Resolution 020/1986 (Ministério do Meio AmbienteCONAMA 1986) and WHO-World Health Organization 2006), such water could be directed to the irrigation of crops as it presented values $\leq 1000$ total coliforms per $100 \mathrm{~mL}$ of water, which is the amount allowed for this activity.

Even with lower values for total coliforms in P1 and $\mathrm{P} 2$ in both studies, E. coli was reported in stream water. P1 was located near the native bushland (a refuge for several species of animals), allowing direct contact of wild animals with the watercourse, and P2 is the nearest from the urban area (Gomes et al. 2007; Mussury et al. 2008).

P3, near the mouth of the "Curral de Arame" stream, showed the highest values for total coliforms and the lowest number of $E$. coli isolated per collection. Studies reported that the collection sites near the mouth have high concentrations of total coliforms, possibly due to the water draining (Poma et al. 2012; Sassoma et al. 2015).

Lee et al. (2014) have studied the fecal human and animal contamination of a watercourse by means of molecular markers. In the present study, they found that such tool, by itself, did not generate enough information to precisely identify the contamination of fecal origin. In order to obtain more reliable results regarding the source of pollution, the markers and rainfall values were assessed together.

The results of total coliforms and rainfall indexes in the collection periods presented a directly proportional relationship. The month when the higher rainfall index occurred, May, was also the month that showed higher values for coliforms (total and thermo-tolerant) (Fig. 3). The month of January showed lower values for coliforms (total and thermo-tolerant) and also a higher rainfall index. According to Gentry-Shields et al. (2012), the effects of rain were studied as a tool to assist fecal contamination detection in river basins of the urban interior, because rain, while flowing into the watercourse, carries along all the contamination present on the streets of the cities and on soils.

The oxytetracycline may also have influenced the proliferation of E. coli, because P3 was the one that presented the lowest number of isolated $E$. coli and the highest concentration of antibiotics (Sato et al. 2015). 
Fig. 2 Total coliforms (NMP/ $100 \mathrm{~mL}$ ) of the six samples taken from the "Curral de Arame" stream, P1, P2, and P3. () represents $E$. coli found at the collection point

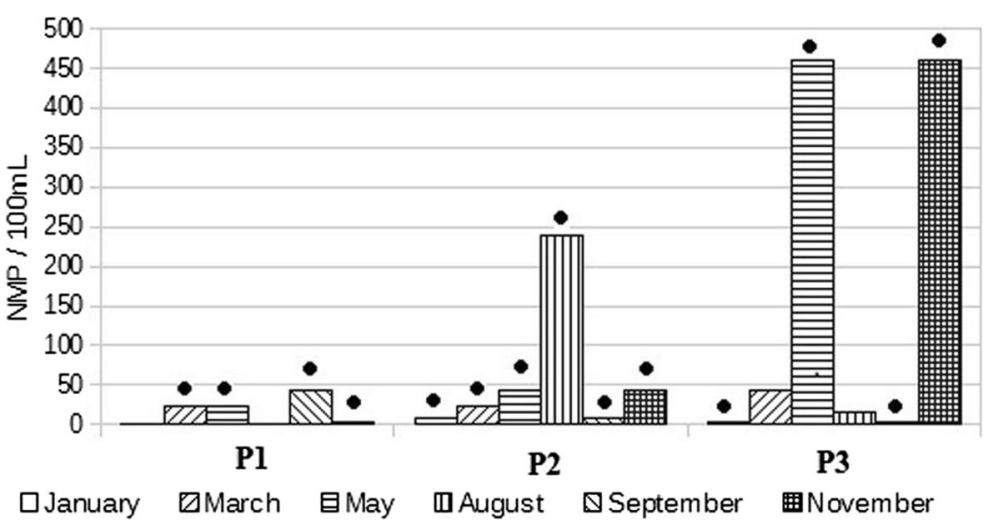

Research on Salmonella spp.

No Salmonella spp. was detected in any of the samples. Several authors studied the presence of Salmonella spp. in natural aquatic environments, as it causes various diseases such as gastroenteritis, bacteremia, and typhoid fever (Abakpa et al. 2015; Masarikova et al. 2016).

\section{Research of Pseudomonas spp.}

In all collection points in the months of March, May, August, and November, Pseudomonas spp. was identified in the water samples of the "Curral de Arame" stream. However, in September, Pseudomonas spp. was observed only in P3, and, in January, there were no Pseudomonas spp. in all the analyzed points.

The proliferation of Pseudomonas spp. in natural environments has become a problem to human health, since it is responsible for opportunistic and nosocomial infections. This is an alarming fact because Pseudomonas spp. presents an intrinsic and acquired resistance due to overuse of antibiotics (Master et al. 2011). Studies have isolated Pseudomonas spp. in aquatic freshwater environments and described the concern with multidrug resistance to antibiotics as exhibited by microorganisms. Pseudomonas spp. presents a high metabolic versatility and can adapt to different conditions and different habitats (Suzuki et al. 2013; Rocha et al. 2015).

\section{Extraction of chlorophyll $a$}

The month of March showed a higher average of chlorophyll $a(0.266)$, differing from the months of September and May when the lowest average (0.081) was verified. The collection points presented no different values among them as to the average of chlorophyll $a$ (Table 3).

The results of the present study corroborate the findings of Ortiz et al. (2008) who have identified an inversely proportional relationship between the number of nutrients and dissolved oxygen. We observed that the point with the highest chlorophyll $a(\mathrm{P} 1)$ had the lowest dissolved oxygen
Fig. 3 Relationship between rainfall index $(\mathrm{mm})$ and coliforms (total and thermo-tolerant) in months of collection at $\mathrm{P} 1, \mathrm{P} 2$, and P3

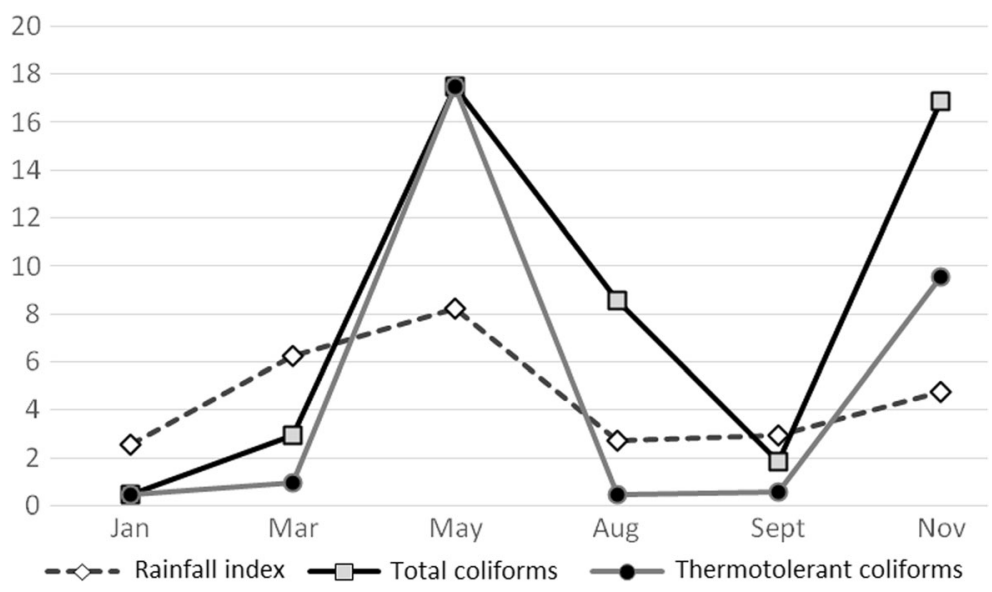


Table 3 Values of chlorophyll $a$ $\left(\mathrm{mg} \mathrm{cm}{ }^{-2}\right.$ ) of the "Curral de Arame" stream expressed on average per month and averages per collection points and standard deviation (SD)

Averages followed by the same letter in columns are statistically equal according to Duncan's test at a 0.05 probability

\begin{tabular}{lll}
\hline Values of chlorophyll $a\left(\mathrm{mg} \mathrm{cm}^{-2}\right)$ & Months & Averages \\
March & May & $0.2669 \pm 0.0425 \mathrm{~A}$ \\
September & $0.0818 \pm 0.0276 \mathrm{C}$ \\
November & $0.1522 \pm 0.1360 \mathrm{BC}$ \\
Points & $0.2139 \pm 0.1085 \mathrm{AB}$ \\
P1 & Averages \\
P2 & $0.1818 \pm 0.1078 \mathrm{~A}$ \\
P3 & $0.2065 \pm 0.1284 \mathrm{~A}$ \\
& $0.1555 \pm 0.1024 \mathrm{~A}$ \\
\hline
\end{tabular}

content (Table 1) and the point with the lowest chlorophyll $a$ (P3) had the highest dissolved oxygen index when compared to the other points (Table 1).

Biological analysis

\section{Micronucleus}

The results for the micronucleus test (MCN) were presented in Table 4. In January and May, the biggest number of MCN in erythrocytes of A. lacustris was observed in P2 (12.0 and 15.2, respectively) and the lowest in P3 (1.800 and 7.600, respectively). In addition, in August and November, $\mathrm{P} 3$ showed the highest number of $\mathrm{MCN}$ (17.0 and 15.0, respectively) and P1 the lowest (6.2 and 8.0, respectively), being different only in August. On the other hand, in September (14.3) and August (13.0), greater numbers of micronuclei could be found.

Comparing the collection points, the highest frequency of MCN in P1 was in September (12.0) and the lowest in August (6.2), being different between them. In P2, the largest number of MCN happened in August (15.8); however, there was no difference between the months. The highest number of $\mathrm{MCN}$, in P3, was found in August (17.0), statistically equal the frequency observed in the months of September and November and different from January and May, with lower micronuclei frequencies. In general, the highest average of micronuclei occurred in P2 (14.2), followed by P3 (11.4) and P1 (8.5), being different among them.

Some authors (Duarte et al. 2012; Ghisi and Oliveira 2013) suggested that the induction of micronuclei is related

Table 4 Frequency of micronuclei (MCN), cell score (CS), and standard deviation (SD) in P1, P2, and P3 spots of the "Curral de Arame" stream in Dourados, MS, Brazil along six months of collection in 2013

\begin{tabular}{|c|c|c|c|c|c|c|c|}
\hline \multirow[t]{2}{*}{ Points } & \multicolumn{7}{|l|}{$\mathrm{MCN}$} \\
\hline & Jan & Mar & May & Aug & Sept & Nov & Averages/month \\
\hline P1 & $8.2 \pm 4.1 \mathrm{abB}$ & - & $8.2 \pm 6.3 \mathrm{abA}$ & $6.2 \pm 3.3 \mathrm{bB}$ & $12.0 \pm 1.5 \mathrm{aA}$ & $8.0 \pm 1.8 \mathrm{abB}$ & $8.5 \pm 4.0 \mathrm{C}$ \\
\hline P2 & $12.0 \pm 3.7 \mathrm{aA}$ & - & $15.2 \pm 5.4 \mathrm{aA}$ & $15.8 \pm 7.1 \mathrm{aA}$ & $15.4 \pm 6.0 \mathrm{aA}$ & $12.8 \pm 5.1 \mathrm{Aab}$ & $14.2 \pm 5.3 \mathrm{~A}$ \\
\hline P3 & $1.8 \pm 1.9 \mathrm{bC}$ & - & $7.6 \pm 3.5 \mathrm{bA}$ & $17.0 \pm 4.6 \mathrm{aA}$ & $15.4 \pm 6.5 \mathrm{aA}$ & $15.0 \pm 5.4 \mathrm{aA}$ & $11.4 \pm 7.2 \mathrm{~B}$ \\
\hline Averages/month & $7.3 \pm 5.3 \mathrm{c}$ & - & $10.3 \pm 6.0 \mathrm{bc}$ & $13.0 \pm 7.0 \mathrm{ab}$ & $14.3 \pm 5.1 \mathrm{a}$ & $11.9 \pm 5.1 \mathrm{ab}$ & - \\
\hline \multirow[t]{2}{*}{ Points } & \multicolumn{7}{|c|}{$\mathrm{CS}$} \\
\hline & Jan & Mar & May & Aug & Sept & Nov & Averages/month \\
\hline P1 & $78.6 \pm 31.1 \mathrm{~dB}$ & $99.6 \pm 9.7 \mathrm{cdB}$ & $112.6 \pm 12.3 \mathrm{cA}$ & $\begin{array}{l}108.8 \pm 13.3 \\
\mathrm{cA}\end{array}$ & $\begin{array}{c}158.6 \pm 31.1 \\
\mathrm{bA}\end{array}$ & $189.0 \pm 16.0 \mathrm{aA}$ & $111.6 \pm 33.3 \mathrm{~A}$ \\
\hline $\mathrm{P} 2$ & $59.4 \pm 38.5 \mathrm{cB}$ & $\begin{array}{l}121.5 \pm 29.7 \\
b B\end{array}$ & $96.8 \pm 36.7 \mathrm{bcA}$ & $\begin{array}{l}111.8 \pm 28.3 \\
\mathrm{bA}\end{array}$ & $\begin{array}{l}165.2 \pm 30.3 \\
\mathrm{aA}\end{array}$ & $\begin{array}{c}180.2 \pm 17.8 \\
\mathrm{aAB}\end{array}$ & $122.5 \pm 50.0 \mathrm{~A}$ \\
\hline P3 & $\begin{array}{l}114.8 \pm 1.6 \\
\mathrm{bcA}\end{array}$ & $\begin{array}{c}170.6 \pm 27.3 \\
\mathrm{aA}\end{array}$ & $\begin{array}{l}113.6 \pm 33.6 \\
\text { bcA }\end{array}$ & $83.6 \pm 14.2 \mathrm{cA}$ & $\begin{array}{l}118.2 \pm 47.9 \\
\mathrm{bA}\end{array}$ & $157.6 \pm 39.4 \mathrm{aB}$ & $126.4 \pm 41.26 \mathrm{~A}$ \\
\hline Averages/month & $84.3 \pm 35.6 \mathrm{~d}$ & $130.6 \pm 37.9 \mathrm{~b}$ & $107.7 \pm 28.5 \mathrm{c}$ & $\begin{array}{l}101.4 \pm 22.5 \\
\mathrm{~cd}\end{array}$ & $147.3 \pm 40.7 b$ & $168.9 \pm 31.2 \mathrm{a}$ & - \\
\hline
\end{tabular}

Averages followed by the same lowercase letter in rows and uppercase letter in columns are statistically equal according to Duncan's test at a 0.05 probability 
to the presence of chemical compounds in the water and that their presence causes changes in the genetic material of the cell. Gutierrez et al. (2015) observed that anthropogenic compounds affected the health of different species of fish, causing damage to the genetic material of the cell and inducing the appearance of micronuclei, mainly in urban and industrial areas. This fact corroborates the results found, as in places (P2 and P3) where the number of MCNs was higher. A higher quantity of metals and oxytetracycline, which favors the use of this technique to evaluate the action of chemical agents in the cell, was also found.

In the months of August and September, a greater amount of MCNs and less rainfall were observed (Fig. 4). Such result indicates the influence of rainfall on the genetic damage that may be due to greater concentration of pollutants in water during periods of low rainfall. This result corroborates the studies by Pavlica et al. (2008) which demonstrated the influence of seasonal variations and the interaction with the contaminants with the amount of MCNs in the cells of mussels, especially in winter. In this way, the appearance of MCNs in erythrocytes of A. lacustris exposed to the water of the "Curral de Arame" stream may be related to both the presence of chemical compounds and the variation in climatic factors and the interactions between them. There was interaction between the points and time for the micronucleus variable.

\section{Comet assay}

\section{Cell score}

The results related to CS were presented in Table 4. The highest damage to the DNA was found in P3 in January
(114.8) and March (170.6) and P2 in August and September (111.8 and 165.2, respectively). In May and November, no difference was observed between those points. The month that showed the highest number of cells with DNA damage was September (147.3), and the lowest number was registered in January (84.3).

P1 and P2 presented a higher number of damaged cells in the month of November (189.0 and 180.2, respectively) and a lower number in January (78.6 and 59.4, respectively). In P3, the highest number of damaged cells was observed in the month of March (170.6) and the lowest in August (83.6).

Changes to DNA observed in erythrocytes of A. lacustris may be related to the existence of genotoxic agents found in the water of the "Curral de Arame" stream (metals and antibiotic). According to Carita and MarinMorales (2008), many of these compounds produce changes in the structure and function of the DNA, which brings on mutations, affects their integrity, and causes breaks and losses of genetic material. Fatima et al. (2014) identified that chronic exposure to metals $(\mathrm{Cr}, \mathrm{Pb}, \mathrm{Ni}$, and $\mathrm{Zn}$ ) in different species of fish originated damages to the genetic material, increased DNA degradation, and caused damages to fish health. As such, those results corroborate with the ones achieved in the present study and indicate that metals may cause impacts to aquatic biota due to bioaccumulation in fish and can affect human beings who are the final consumers in the food chain.

Another factor that influences the concentration of chemical compounds in aquatic environments is seasonal variation. Rainfall data, when compared with the Comet Assay, indicated that the months when there was a higher DNA damage in exposed fish (September and November) were those when the amount of rainfall was scarce (Fig. 4).
Fig. 4 Comparison of rainfall index $(\mathrm{mm})$ with the number of micronuclei $(\mathrm{MCN})$ and cell score (CS) according to months

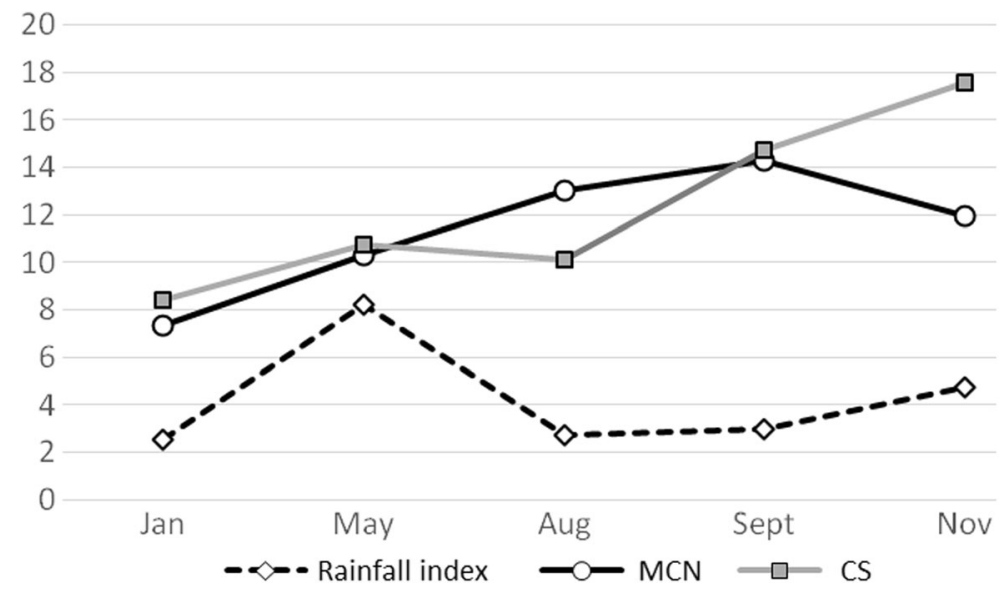


This fact suggests that this parameter is related to the increase of genotoxicity in fish. Scalon et al. (2010) observed greater genotoxic damage in the cells of Hyphessobrycon luetkenii fish during Spring using the Comet Assay technique. Their results indicate the possible influence of seasonality in the concentration of chemical compounds; however, this is not the only influent factor in this respect. As such, these results highlight the influences of organic compounds on the potential induction of DNA damage to the exposed organisms, especially in periods with low rainfall, showing the influence of urban and agricultural activities on the water quality of the "Curral do Arame" stream.

\section{Conclusion}

The tests used for stream monitoring were efficient to establish the anthropic interference that water receives. P3 presented a higher contamination (high levels of metals, higher concentrations of total coliforms and chlorophyll $a$, and major genetic changes). This location is the closest to the mouth of the river and all contamination (agricultural and urban) received in this path was dragged by the water. According to the CONAMA (357/2005), stream water could be directed to some human activities (to supply for human consumption after conventional or advanced treatment; irrigation of trees, cereals, and fodder crops, amateur fishing, secondary contact recreation, and watering of animals). However, the results proved the impossibility of using this water for such activities, through direct contact with the water or by fish consumption. The population is then subjected to contamination by bacteria or genotoxic agents.

Acknowledgments The authors thank Dr. Jorge Luiz Raposo Junior for carrying out the analysis of metals, Dr. Yzel Rondon Súarez for lending the equipment Hanna HI 9829 Multiparameter, the financial help of the Foundation for the Support to Development of Education, Science and Technology of the State of Mato Grosso do Sul-FUNDECT, and the National Scientific and Technological Development Center-CNPq for the master's scholarships.

\section{References}

Abakpa, G. O., Umoh, V. J., Ameh, J. B., Yakubu, S. E., Kwaga, J. K. P., \& Kamaruzaman, S. (2015). Diversity and antimicrobial resistance of Salmonella enterica isolated from fresh produce and environmental samples. Environmental Nanotechnology, Monitoring and Management, 3, 38-46. https://doi.org/10.1016/j.enmm.2014.11.004.

Andreu, V., Gimeno-García, E., Pascual, J. A., Vazquez-Roig, P., \& Picó, Y. (2016). Presence of pharmaceuticals and heavy metals in the waters of a Mediterranean coastal wetland: potential interactions and the influence of the environment. Science of the Total Environment, 540, 278-286. https://doi. org/10.1016/j.scitotenv.2015.08.007.

APHA, AWWA, \& WEF. (2005). Standard methods for the examination of water and wastewater (21st ed.p. 1368). Washington, D.C: APHA, AWWA, \& WEF.

Ayres, M., Junior, M. A., Ayres, D. L., \& Santos, A. S. D. (2005). BioEstat Versão 4.0: Aplicações estatísticas nas áreas das Ciências Biológicas e Médicas. Sociedade Civil Mamirauá, MCT-CNPq, Imprensa Oficial do Estado do Pará. 324.

Bayen, S. (2012). Occurrence, bioavailability and toxic effects of trace metals and organic contaminants in mangrove ecosystems: a review. Environment International, 48, 84-101. https://doi.org/10.1016/j.envint.2012.07.008.

Bermudez, G. M. A., Rodriguez, J. H., \& Pignata, M. L. (2009). Comparison of the air pollution biomonitoring ability of three Tillandsia species and the lichen Ramalina celastri in Argentina. Environmental Research, 109(1), 6-14. https://doi.org/10.1016/j.envres.2008.08.014.

Callisto, M., \& Gonçalves Jr., J. F. (2002). A vida nas águas das montanhas. Ciência Hoje, 31, 68-71.

Callisto, M., Gonçalves Jr., J. F., \& Moreno, P. (2005). Invertebrados aquáticos como bioindicadores. Navegando o Rio das Velhas das Minas aos Gerais, 1, 1-12.

Carita, R., \& Marin-Morales, M. A. (2008). Induction of chromosome aberrations in the Allium cepa test system caused by the exposure of seeds to industrial effluents contaminated with azo dyes. Chemosphere, 72(5), 722-725. https://doi. org/10.1016/j.chemosphere.2008.03.056.

Duarte, I. M., Dias, M. C., David, J. A. O., \& Matsumoto, S. T. (2012). A qualidade da água da Lagoa Jacuném (Espírito Santo, Brasil) em relação a aspectos genotóxicos e mutagênicos, mensurados respectivamente pelo ensaio do cometa e teste do micronúcleo em peixes da espécie Oreochromis niloticus. Brazilian Journal of Bioscience, 10, 211-219.

EMBRAPA-Empresa Brasileira de Pesquisa Agropecuária. (2014). Guia Clima. Avalable from: http://www.cpao. embrapa.br/clima/?lc=site/banco-dados/base_dados. Acessed on: 24 Macrh 2014.

Fatima, M., Usmani, N., Mobarak Hossain, M., Siddiqui, M. F., Zafeer, M. F., Firdaus, F., \& Ahmad, S. (2014). Assessment of genotoxic induction and deterioration of fish quality in commercial species due to heavy-metal exposure in an urban. Archives of Environmental Contamination and Toxicology, 67(2), 203-213. https://doi.org/10.1007/s00244-014-0024-8.

Fietz, C. R., \& Fisch, G. F. (2008). O Clima da Região de Dourados, MS-Embrapa (MS). Dourados: Embrapa Agropecuária Oeste, 92(2), 1-34.

Gemmell, M. E., \& Schmidt, S. (2013). Is the microbiological quality of the Msunduzi River (KwaZulu-Natal, South Africa) suitable for domestic, recreational, and agricultural purposes? Environmental Science and Pollution Research International, 20(9), 6551-6562. https://doi.org/10.1007 /s11356-013-1710-1. 
Gentry-Shields, J., Rowny, J. G., \& Stewart, J. R. (2012). HuBac and nifH source tracking markers display a relationship to land use but not rainfall. Water Research, 46(18), 61636174. https://doi.org/10.1016/j.watres.2012.09.016.

Ghisi, N. C., \& Oliveira, E. C. (2013). Evidence of contamination in the main body of the public water supply of campo mourão-PR: an analysis from a bioindicator of enviromental quality. SaBios-Revista de Saúde e Biologia, 8, 13-22.

Gomes, A. A., Mussury, R. M., Scalon, S. P. Q., Watthier, F., Cunha, K. A. A., \& Scalon Filho, H. (2007). Avaliação Do Impacto Da Fragmentação De Florestas Nativas Sobre A Mesofauna Edáfica Na Região De Dourados-MS. Ciência Agrotecnologia Lavras, 31(3), 612-618. https://doi. org/10.1590/S1413-70542007000300003.

Gontijo, A. M. M. C., \& Tice, R. (2003). Teste do cometa para a detecção de dano no DNA e reparo em células individualizadas. Mutag. Amb., Ed. Ulbra, pp 173-200.

Goulart, M., \& Callisto, M. (2003). Bioindicadores de qualidade de água como ferramenta em estudos de impacto ambiental. Revista da FAPAM, 2, 156-164.

Gutierrez, J. M., Villar, S., \& Plavan, A. A. (2015). Micronucleus test in fishes as indicators of environmental quality in subestuaries of the Río de la Plata (Uruguay). Marine Pollution Bulletin, 91(2), 518-523. https://doi.org/10.1016 j.marpolbul.2014.10.027.

Heddle, J. A., Hite, M., Kirkhart, B., Mavournin, K., Mcgregor, J. T., Newell, G. W., \& Salamone, N. F. (1983). The induction of micronuclei as a mensure genotoxicity. Mutation Research, 123(1), 61-118. https://doi.org/10.1016/01651110(83)90047-7.

IBGE - Instituto Brasileiro de Geografia e Estatística. Cidades 2013. Available from: http://www.cidades.ibge.gov. br/xtras/perfil.php?lang=\&codmun=500370\&searchmatogrosso-do-sul dourados. Acessed on: 22 Feb 2016.

Kasprzyk-Hordern, B., Dinsdale, R. M., \& Guwy, A. J. (2009). Illicit drugs and harmaceuticals in the environment-forensic applications of environmental data, part 2: pharmaceuticals as chemical markers of faecal water contamination. Environmental Pollution, 157(6), 1778-1786. https://doi. org/10.1016/j.envpol.2009.02.019.

Kittinger, C., Marth, E., Reinthaler, F. F., Zarfel, G., PichlerSemmelrock, F., Mascher, W., Mascher, G., \& Mascher, F. (2013). Water quality assessment of a Central European River - does the Directive 2000/60/EC cover all the needs for a comprehensive classification? Science of the Total Environment, 447, 424-429. https://doi.org/10.1016/j. scitotenv.2013.01.015.

Lee, D. Y., Lee, H., Trevors, J. T., Weir, S. C., Thomas, J. L., \& Habash, M. (2014). Characterization of sources and loadings of fecal pollutants using microbial source tracking assays in urban and rural areas of the Grand River Watershed, Southwestern Ontario. Water Research, 53, 123-131. https://doi.org/10.1016/j.watres.2014.01.003.

Lima, P. A. de. 1999. Ocupação do fundo de vale do córrego laranja doce na cidade de Dourados-MS. Análise da proposta de implantação de um parque ecológico. Dissertação de mestrado-UNESP, Presidente PrudenteSP.

Masarikova, M., Manga, I., Cizek, A., Dolejska, M., Oravcova, V., Myskova, P., Karpiskova, R., \& Literak, I. (2016). Salmonella enterica resistant to antimicrobials in wastewater effluents and black-headed gulls in the Czech Republic, 2012. Science of the Total Environment, 542(Pt A), 102107. https://doi.org/10.1016/j.scitotenv.2015.10.069.

Master, R. N., Clark, R. B., Karlowsky, J. A., Ramirez, R., \& Bordon, J. M. (2011). Analysis of resistance, cross-resistance and antimicrobial combinations for Pseudomonas aeruginosa isolates from 1997 to 2009. International Journal of Antimicrobial Agents, 38(4), 291-295. https://doi. org/10.1016/j.ijantimicag.2011.04.022.

Ministério do Meio Ambiente-CONAMA. 1986. Resolução n 20, de 18 de junho de 1986. Diário Oficial da União, 1-15.

Ministério do Meio Ambiente-CONAMA. 2005. Resolução $n^{\circ}$ 357, de 17 de março de 2005. Dispõe sobre a classificação dos corpos de água e diretrizes ambientais para o seu enquadramento, bem como estabelece as condições e padrões de lançamento de efluentes, e dá outras providências. Diário Oficial da União, 58-63.

Mussury, R. M., Scalon, S. P. Q., Gomes, A. A., Batista, M. R., \& Scalon-Filho, H. (2008). Flutuação populacional da mesofauna em fragmentos de mata na região de Dourados MS. Ciência Agrotecnologia Lavras, 32(2), 645-650. https://doi.org/10.1590/S1413-70542008000200047.

Okeke, B. C., Thomson, M. S., \& Moss, E. M. (2011). Occurrence, molecular characterization and antibiogram of water quality indicator bacteria in river water serving a water treatment plant. Science of the Total Environment, 409(23), 4979-4985. https://doi.org/10.1016/j.scitotenv.2011.07.029.

Oliveira, K. M. P., Julio, P. D. S., \& Grisolia, A. B. (2013). Antimicrobial susceptibility profile of Pseudomonas spp. isolated from a swine slaughterhouse in Dourados, Mato Grosso do Sul State, Brazil. Revista Argentina de Microbiología, 45(1), 57-60.

Ortiz, N., Godói, E. L., Polakiewicz, L., \& Pires, M. A. F. (2008). Monitoramento de águas de superfície densamente poluídas-O córrego Pirajuçara-localizado na Região Metropolitana de São Paulo. Revista Exacta, 6, 245-257.

Pavlica, M., Podrug, M., Stambuk, A., Cvjetko, P., \& Klobucar, G. I.,. V. (2008). Seasonal variability in micronuclei induction in haemocytes of mussels along the Eastern Adriatic Coast. Polish Journal of Environmental Studies, 5, 765-771.

Poma, H. R., Gutiérrez Cacciabue, D., Garcé, B., Gonzo, E. E., \& Rajal, V. B. (2012). Towards a rational strategy for monitoring of microbiological quality of ambient waters. Science of the Total Environment, 433, 98-109. https://doi.org/10.1016 j.s.scitotenv.2012.06.019.

Ramsdorf, W. A., Guimarães, F. S. F., Ferraro, M. V. M., Gabardo, J., Trindade, E. S., \& Cestari, M. M. (2009). Establishment of experimental conditions for preserving samples of fish blood for analysis with both comet assay and flow cytometry. Mutation Research, 673(1), 78-81. https://doi.org/10.1016 /j.mrgentox.2008.11.010.

Ribeiro, E. V., Magalhães Junior, A. P., Horn, A. H., \& Trindade, W. M. (2012). Metais Pesados E Qualidade Da Agua Do Rio São Francisco No Segmento Entre Três Marias E PiraporaMg: Índice De Contaminação. Geonomos, 20(1), 49-63.

Rocha, M. P., Dourado, P. L. R., Rodrigues, M. S., Raposo Jr., J. L., Grisolia, A. B., \& Oliveira, K. M. P. (2015). The influence of industrial and agricultural waste on water quality in the Água Boa stream (Dourados, Mato Grosso do Sul, Brazil). Environmental Monitoring and Assessment, 187, 1-12. 
Rowny, J. G., \& Stewart, J. R. (2012). Characterization of nonpoint source microbial contamination in an urbanizing watershed serving as a municipal water supply. Water Research, 46(18), 6143-6153. https://doi.org/10.1016/j. watres.2012.09.009.

Santos, G. C., \& Monteiro, M. (2004). Sistema orgânico de produção de alimentos. Alimentos e Nutricao Araraquara, 15(1), 73-86.

Sassoma, I. T. L., Sousa, I. F., Aguiar Netto, A. O., \& Carvalho, C. M. (2015). Avaliação Temporal E Espacial De Caracteristicas Físicoquímicas Em Águas Superficiais Do Rio Catumbela, Angola. Revista Brasileira de Agricultura Irrigada, 9(3), 113-126.

Sato, J. P. H., Takeuti, K. L., Daniel, A. G. S., Koerich, P. K. V., Bernardi, M. L., \& Barcellos, E. S. N. (2015). Associação entre fatores de virulência e resistência antimicrobiana de Escherichia coli enterotoxigênicas isoladas de leitões com diarreia no Brasil. Acta Scientiae Veterinariae, 43, 1329.

Scalon, M. S. C., Rechenmacher, C., Siebel, A. M., Kayser, M. L., Rodrigues, M. T., Maluf, S. W., Rodrigues, M. A. S., \& Silva, L. B. (2010). Evaluation of Sinos River water genotoxicity using the comet assay in fish. Brazilian Journal of Biology, 70(4 suppl), 1217-1222. https://doi.org/10.1590/S151969842010000600011.

Schipper, P. N. M., Bonten, L. T. C., Plette, A. C. C., \& Moolenaar, S. W. (2008). Measures to diminish leaching of heavy metals to surface waters from agricultural soils. Desalination, 226(13), 89-96. https://doi.org/10.1016/j.desal.2007.02.100.

Schmid, W. (1975). The micronucleus test. Mutation Research, 31(1), 9-15. https://doi.org/10.1016/0165-1161(75)90058-8.

Silva, N., Junqueira, V. C. A., Silveira, N. F. A., Taniwaki, M. H., Santos, R. F. S., \& Gomes, R. A. R. (2010). Manual de métodos de análises microbiológicas de alimentos e água. Ed. Varela, 4, pp 624.
Silva, R. R. P., Pires, O. R., \& Grisolia, C. K. (2011). Genotoxicity in Oreochromis niloticus (Cichlidae) induced by Microcystis spp bloom extract containing microcystins. Toxicon, 58(3), 259-264. https://doi.org/10.1016/j.toxicon.2011.06.005.

Siqueira, N. S., \& Rodrigues, L. (2009). Biomassa Perifítica em Tanques-Rede de Criação de Tilápia do Nilo-Oreochromis niloticus (Linneau, 1758). Boletim do Instituto de Pesca, 35, 181-190.

Suzuki, Y., Kajii, S., Nishiyama, M., \& Iguchi, A. (2013). Susceptibility of Pseudomonas aeruginosa isolates collected from river water in Japan to antipseudomonal agents. Science of the Total Environment, 450, 148-154.

Tiefenthaler, L., Stein, E. D., \& Schiff, K. C. (2011). Levels and patterns of fecal indicator bacteria in stormwater runoff from homogenous land use sites and urban watersheds. Journal of Water and Health, 9(2), 279-290. https://doi.org/10.2166 /wh.2010.056.

Vazquez-Roig, P., Andreu, V., Onghena, M., Blasco, C., \& Picó, Y. (2011). Assessment of the occurrence and distribution of pharmaceuticals in a Mediterranean wetland (L'Albufera, Valencia, Spain) by LC-MS/MS. Analytical and Bioanalytical Chemistry, 400(5), 1287-1301. https://doi. org/10.1007/s00216-011-4826-5.

Ventura, B. C., Angelis, D. F., \& Marin-Morales, M. A. (2008). Mutagenic and genotoxic effects of the atrazine herbicide in Oreochromis niloticus (Perciformes cichlidae) detected by the micronuclei test and the comet assay. Pesticide Biochemistry and Physiology, 90(1), 42-51. https://doi. org/10.1016/j.pestbp.2007.07.009.

WHO - World Health Organization. (2006). Guidelines for the safe use of wastewater, excreta and greywater: excreta and greywater use in agriculture (Vol. 4, p. 182). Washington, DC: World Health Organization. 